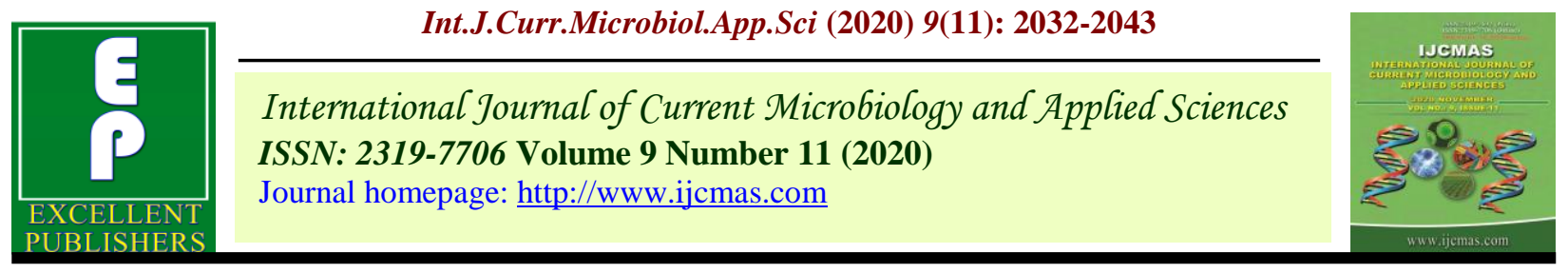

Original Research Article

https://doi.org/10.20546/ijcmas.2020.911.242

\title{
Genetic Study of the Resistance of Twelve (12) Varieties of Vegetable Cowpea [Vigna unguiculata (L.) Walp. ] to Cowpea Aphid- Borne Mosaic Virus, Burkina FASO
}

\author{
Nanama Joseph ${ }^{1}$, Barro Antoine ${ }^{2 *}$, Batieno Benoit Joseph ${ }^{3}$, Dieni Zakaria ${ }^{3}$, \\ Kiebre Zakaria ${ }^{1}$, Coulibaly Zinmanké ${ }^{1}$ and Sawadogo Mahamadou ${ }^{1}$ \\ ${ }^{1}$ Université Joseph KI-ZERBO, ${ }^{2}$ Université de Dédougou, BP, ${ }^{3}$ Institut de l'Environnement et \\ de Recherches Agricoles, Ouagadougou, Burkina Faso \\ *Corresponding author
}

\begin{abstract}
A B S T R A C T
Cowpea [Vigna unguiculata (L.) Walp.] is a legume whose immature pods are consumed and marketed. However, it suffers yield losses due to attacks of aphid-transmitted mosaic disease. The present work is a study of the genetic resistance of twelve (12) varieties of vegetable cowpea to Cowpea Aphid-Borne Mosaic Virus (CABMV) at Kamboinsé. The objective of the study was to contribute to the enhancement and improvement of yields through the development of vegetable cowpea varieties resistant to $C A B M V$. The study was conducted in a screen house at Kamboinsé research station using a randomized complete block design with three (3) replications, all inoculated with CABMV. The study showed the existence of a large genetic variability within the varieties studied. The analysis of variance showed very highly significant differences $(\mathrm{P}=0.0001)$ between the twelve (12) vegetable cowpea varieties in terms of symptom severity. Principal Component Analysis (PCA) of the variables revealed the parameters that discriminate between varieties. High correlations levels were observed between several variables. The vegetable cowpea varieties IT85F-2089-5, IT85F-2082 and Telma which had low severity values ( 1 and 2), the area under disease progress curve (AUDPC) and a high weight of one hundred seed have been identified as the best varieties of vegetable cowpea. The variety IT85F-2089-5 have been identified as an elite variety because of a low severity (1), early flowering date (40 days), early green cowpea date (51 days), early maturity date (57 days) and a low value for the AUDPC (9). These varieties can thus contribute to the improvement of vegetable cowpea production by producers in Burkina Faso.
\end{abstract}

\section{Introduction}

Cowpea, [Vigna unguiculata (L.) Walp. ], is a food and fodder legume with great genetic and agronomic diversity. It is cultivated in the world on an area of about 12316878 ha and its production is estimated at 6.99 million tons of dry seeds of which $96.04 \%$ are produced in Africa (FAOSTAT, 2016). In Burkina Faso, cowpea is the fourth most important crop in terms of production after sorghum $(1,742,116$ t), maize $(1,583,421 \mathrm{t})$ and millet $(1,056,931$ 
t) (FAOSTAT, 2016). In terms of diet, cowpea plays an important role in the nutritional balance of the diets of rural populations and animals in savannah areas and the Sahel (Tignegre, 2000). It contains 20-25\% protein and 64\% carbohydrates (Jackson, 2009; Modu et al., 2010). According to Kidigodi, (1985), thanks to the symbiotic association between its roots and the nodules carrying bacteria of the Rhizobium genus, atmospheric nitrogen fixers, it also contributes to soil improvement.

Despite the development and vulgarization of varieties adapted to Burkina Faso, the production efforts of cowpea are subject to abiotics and biotics constraints that reduce the yields considerably.

One of the major constraints is that of attacks by the aphid-transmitted mosaic virus or CABMV (Reeves, 1983). The yield losses due to GBMV can be up to $100 \%$ in subSaharan Africa if no protective measures are taken (Singh and Jackai, 1985).

The yield losses ranging from $7 \%$ to $60 \%$ in about ten varieties have been attributed to this virus in Burkina Faso (NEYA, 2002). The varietal resistance is an adequate method in the control of this viral disease (NUALSRI et $a l ., 2000)$. However, much work on vegetable cowpea genotypes has not yet been undertaken in Burkina Faso. This is why the general objective of this study is to contribute to the improvement the yields of vegetable cowpea through the development resistant varieties of vegetable cowpea to Cowpea Aphid-Borne Mosaic Virus in Burkina Faso. Specifically, the aim is to (i) describe the reaction of the varieties of vegetable cowpea to mechanical inoculation of CABMV; (ii) determine the harvest date of "vegetable cowpea" and (iii) identify the sources of resistance to CABMV.

\section{Materials and Methods}

\section{Plant Material}

The plant material of the study consists of twelve (12) varieties of vegetable cowpea, including one (01) from Burkina Faso of cream colour with a smooth texture and eleven (11) from Nigeria with red and white coloured seeds with mostly smooth texture.

\section{Technical equipment}

The study required the use of pots; a hoe for sowing and weeding; a mortar and pestle for crushing the leaves for the inoculum; and sterilized sand used in the crushing; a watering can and a cup for watering the plants; an electronic scale of the ZOHAUS brand which was used for weighing the different weighed materials (infected leaves, grains); a "SPAD meter" which made to estimate the chlorophyll content of each plant.

\section{Experimental site}

The work was carried out in a greenhouse at the Formation and Agricultural, Environment Research Center (CREAF) in Kamboinsé. The center is located in the northern Sudanian sector of the Sudanian domain (Guinko, 1984; Thiombiano and Kampmann, 2010), alternating two unevenly distributed seasons. It is located at $12^{\circ} 28$ North latitude and $1^{\circ} 32$ West longitude and at an altitude of $296 \mathrm{~m}$. The station's average rainfall varies from 700 $\mathrm{mm}$ to $900 \mathrm{~mm}$ per year, with a relative humidity between 60 and $70 \%$. During the $2017 / 2018$ crop year, the annual rainfall was $843.5 \mathrm{~mm}$ in 50 rainy days (Météo INERA, 2018). The soils are ferruginous tropical, leached, hydromorphic, low humus to pseudogley in association with lithosols on ferruginous armour (Zougmore et al., 2004). 


\section{Experimental device}

The experimental device used was a randomized complete block design with three (3) repetitions. Each repetition consisted of 12 pots each containing one variety. Each pot corresponded to an elementary plot and contained a single plant.

\section{Conduct of the trial}

The test was carried out in a screen house of the cowpea breeding unit, sheltered from insects, particularly aphids. Before the test was set up, a mixture in the proportions of $2 / 3$ soil and $1 / 3$ sand was packed in bags and fired using a double-bottomed drum to eliminate pathogenic organisms.

The sterilization temperature was $100^{\circ} \mathrm{C}$. The jars that had been used as a basic plot were then cleaned and sterilized with bleach for a period of 24 hours and then filled with the cooled soil and sand mixture. Each jar was labelled in the different repetitions.

Maintenance operations consisted of digging as needed to facilitate water infiltration to promote plant growth, application of fertilizers and insecticide treatments. Each pot received NPK fertilizer formula 14-23-14-6S$1 \mathrm{~B}$ for 15 days after planting, at a rate of $2 \mathrm{~g}$ per pot. The insecticide used was "PACHA 25 EC $\quad(15 \mathrm{~g}$ lamdacyhalothrin $+10 \mathrm{~g}$ acetamiprid)" a broad spectrum foliar systemic insecticide at a rate of $2 \mathrm{ml}$ per litre of water. Treatments were made at the flower bud and pod-forming stages.

\section{Inoculum preparation and screening of cowpea plants}

To obtain the inoculum for screening varieties in the trial, a variety of cowpea susceptible to CABMV, local Gorom was sown and infested with CABMV twelve (12) days after sowing
(DAS), corresponding to the two-leaf stage, in order to multiply the isolate for infestation.

The test was set up at the date of infestation of the local Gorom variety, so that the twoleaf stage of the test plants coincided with the appearance of symptoms on the susceptible variety.

At the time of screening (11 days after sowing), the young leaves of the susceptible cowpea variety (local Gorom) infected by CABMV were crushed using a laboratory mortar with sterilized sand at a w/v crushing ratio of $1 \mathrm{~g} / 10 \mathrm{ml}$.

The grind was then homogenized in $0.01 \mathrm{M}$ sodium phosphate buffer, $\mathrm{pH} 7.4$ and carborundum 600 mesh which is an abrasive product. Using the pestle dipped in the extract, the upper leaf surface of the young plants in the test to be infested was gently rubbed and then rinsed with distilled water to avoid over-inoculation (NEYA, 2011 and BARRO, 2016). The inoculated plants were kept under glass for symptom observation.

\section{Data Collection}

The data collection concerned all the elementary plots (pots). Some data were observed, others measured or calculated and concerned the $50 \%$ flowering day; the SPAD; the "vegetable cowpea" date; the 95\% maturity date; the number of pods per plant; the weight of pods; the weight of one hundred (100) seeds; the weight of seeds; the number of seeds per pod; the date of symptom emergence noted from the 6th to the 21 st day after inoculation; the severity of symptoms noted on a six-class scale (0-5) at the 21 st and 30th day after inoculation (NEYA, 2011; BARRO, 2016) and the area under disease progress curve (AUDPC) proposed by Shaner and Finnay (1977). 


\section{Statistical analysis of the data}

The collected data were subjected to a onefactor analysis of variance (ANOVA) to compare the means of the variables at the $5 \%$ significance level $(\mathrm{P}<0.05)$ and the results are presented in tabular form. The ANOVA was performed using SAS (Statistical Analysis System) Enterprise version 4.3 software.

The correlations between the quantitative variables were estimated using the Pearson correlation coefficient. A Principal Component Analysis (PCA) was performed using XLSTAT 2016 to show the association of the characteristics and an identification of the main discriminant variables within the varieties used.

\section{Results and Discussion}

\section{Date of symptom onset and severity}

The results of the analysis of variance for date of symptom emergence and severity are presented in Table 1. The symptoms appeared in all varieties between the 6th and 13th day after inoculation with an average of 7 days. The varieties IT85F-867-5, baguette, IT85F2682, IT83S-911 and baguettegrimpant were the first to show the disease as early as day 6 after inoculation. The statistical analysis revealed a highly significant difference between varieties for this parameter $(\mathrm{p}=0.0008)$. The analysis of variance (ANOVA) for disease symptom severity was highly significant at $30 \mathrm{DAI}$ and significant at 21 DAI with a mean severity of 4 out of 5 at 30 DAI. The varieties IT83S-872, IT85F-8675, IT83S-911, niébé baguette grimpant showed severe symptoms (5) at 30 DAI, whereas the varieties IT85F-2089-5 (1), IT85F-2082, Telma (2) showed less symptoms. The different symptoms observed are presented in picture 1 .
The values for the area under disease progress curve (AUDPC) are shown in Table 1. The values ranged from 9 to 45 for the different cowpea varieties evaluated, with a mean of 28.12. The analysis of variance of the values of the area under disease progress curve (AUDPC) revealed a highly significant difference $(\mathrm{P}=0.0001)$ between the different varieties with a coefficient of variation of 13.28. Disease progression was low in IT85F2089-5(9) and Telma (13), whereas in the varieties baguettegrimpant, IT83S-872 and IT85F-867-5 with an area under disease progress curve of 42 and 40.5 respectively were the most infected.

\section{Phenological parameters}

Table 2 presents the results of the analysis of variance for the phenological parameters. Flowering at $50 \%$ varied from 34 to 47 DAS with a coefficient of variation (CV) of $4.46 \%$. The mean value of the number of days at $50 \%$ flowering was 47.72 days after sowing. The variety IT85F-2887 was the first to reach 50 $\%$ flowering at 36 DAS while the variety Telma reached $50 \%$ flowering late at 46 DAS.

The number of days at $95 \%$ maturity ranged from 55 to 73 DAS. The average number of days at $95 \%$ maturity is 61 DAS. The varieties IT85F-2089-5 and baguette were earlier (58 DAS and 57 DAS) compared to the variety Komsaré which reached this stage at 68 DAS. The analysis of variance was highly significant $(\mathrm{P}=0.0001)$ between varieties for the $95 \%$ maturity characteristic.

The vegetable Cowpea Date ranged from 49 JAS (niébé Baguette, IT85F-2887, IT83S-911 and niébé baguette grimpant) to 57 DAS (Komsaré, IT85F-2682) with an average value of 52 DAS. The analysis of variance (ANOVA) revealed a highly significant difference $(p=0.0006<0.05)$ between varieties 
with a coefficient of variation of 4.62 (Table 4).

\section{Performance components}

The results of the weight of one-hundred (100), seeds the weight seed per unit plot, number of pods per plant and number of seeds per pod are presented in Table 3 .

The weight of one hundred seed varied from $8.55 \mathrm{~g}$ to $22.7 \mathrm{~g}$ with an average of $13.41 \mathrm{~g}$. For this parameter, the Coefficient of Variation (CV) was $13.25 \%$. The variety Telma had the highest weight of one hundred seed $(20.05 \mathrm{~g})$ and the IT83S-872 variety had the lowest weight $(9.4 \mathrm{~g})$. The analysis of variance revealed a highly significant difference $(\mathrm{P}=0.0001)$ for the weight of onehundred seeds parameter.

The weight of the seeds, with an average value of $10.36 \mathrm{~g}$, ranged from $4.5 \mathrm{~g}$ to $14.5 \mathrm{~g}$. The variety IT85F-2682 had the lowest weight of seeds at $4.5 \mathrm{~g}$ and for the variety Telma, the highest weight of seeds at $14.5 \mathrm{~g}$, followed by Komsaré (14.3g), IT85F-2089-5 (12.7g), IT85F-867-5 (11.8g), IT85F-2082 $(11.03 \mathrm{~g})$. For this parameter the statistical analysis showed a significant difference between the varieties used at the 5\% threshold $(\mathrm{p}=0.023)$ with a coefficient of variation of $28.96 \%$.

As for the variable number of pods per plant, the analysis of variance showed no significant difference between the different varieties used $(\mathrm{P}=0.18>0.005)$.

\section{Study of correlations}

Table 4 shows the correlation matrix resulting from the analysis. The study of the correlations between the twelve (12) variables showed that some of them are significantly correlated, either positively or negatively. The analysis of the correlation matrix shows indeed positive and highly significant correlation coefficients between the severity at the 21st and the severity at the 30th day after inoculation (DAI) ( $\mathrm{r}=0.73)$, between the variables $95 \%$ maturity and $50 \%$ flowering $(\mathrm{r}=0.63)$, AUDPC and severity at the 30th DAI $(r=0.93)$. The highly and positive correlations were also revealed between the vegetable cowpea date and the $50 \%$ flowering date $(r=0.64)$, between the vegetable cowpea date and the $95 \%$ maturity date $(r=0.66)$, then between seeds weight and the number of seeds per pod $(r=0.52)$. The weight of one hundred seeds is negatively correlated with the severity at 21 DAI $(\mathrm{r}=-0.52)$, and AUDPC ( $\mathrm{r}=-0.54)$.

\section{Character association}

The components provide an estimate of the percentage of variability observed. The results of the Principal Component Analysis (PCA) carried out with the different parameters show the association of the characters and the variables that form the different axes (Table 5). Axis 1 and 2 explain $64.40 \%$ of the genetic variability of the varieties. The parameters contributing positively to the formation of axis 1 are severity at 21, $30 \mathrm{DAI}$ and AUDPC and those contributing negatively are SPAD and weight of onehundred-seed, date of symptom emergence and seeds weight. This axis expresses $42.28 \%$ of the total genetic variability. Axis 2 expresses $21.56 \%$ of the variability. The variables $50 \%$ flowering, $95 \%$ maturity, vegetable cowpea date and the number of seeds per pod contribute highly and positively to the formation of this axis.

Different types of symptoms developed a few weeks after inoculation of the varieties studied. The early emergence of symptoms from the sixth day after inoculation in some varieties such as niébé baguette, niébé 
baguette grimpant, IT83S-911, IT85F-867-5 and Telma would suggest a greater susceptibility to CABMV in these varieties. Some susceptible varieties showed both green and yellow mosaic with leaf curling (IT83S911), yellow mosaic with leaf distortion (IT85F-2682), followed by a reduction in plant size.

These symptoms are similar to those noted by (FISCHER and LOCKHART, (1976); NEYA (2002) and BARRO (2016) who screened local and improved varieties with the same virus. According to NEYA (2011), the molecular determinants of this symptomatological diversity are not yet known. The induction of symptoms of reduced severity reinforces the status of resistance to the virus (BARRO, 2016). This would partly explain the negative correlation between weight of one-hundred-seed and severity and area under disease progression curve.

The levels of infection varied significantly from one variety to another. The significant difference after analysis of variance for the symptom severity parameter would indicate the existence of high genetic variability in resistance to CABMV in the varieties. Severity classes 1 and 2 presented by varieties such as IT85F-2089-5, IT85F-2082 and Telma show that these varieties would be resistant to CABMV.

On the other hand, varieties such as Niébé baguette grimpant and IT85F-867-5 with a severity rating of 5 would be the most susceptible. ORAWU et al., (2012) also obtained a severity class 5 for a local cowpea variety 'Ebelat', which is susceptible to CABMV.

Table.1 Results of the analysis of variance of the date of symptom emergence, severity and area under disease progress curve for the twelve (12) vegetable cowpea varieties studied

\begin{tabular}{|l|l|l|l|l|l|}
\hline Variables & Minimum & Maximum & $\begin{array}{l}\text { Overall } \\
\text { average }\end{array}$ & P-Value (5\%) & CV (\%) \\
\hline $\begin{array}{l}\text { Date of symptom } \\
\text { emergence }\end{array}$ & 6 & 13 & 7 & $0,0008^{*}$ & $\mathbf{1 7 , 1 2}$ \\
\hline Severity on Day 21 (DAI) & 0 & 5 & 3 & $0,0001^{* *}$ & $\mathbf{2 8 , 6 4}$ \\
\hline Severity at Day 30 (DAI) & 1 & 5 & 4 & $0,0001^{* *}$ & $\mathbf{8 , 4 1}$ \\
\hline AUDPC & 9 & 45 & 28,12 & $0,0001^{* *}$ & $\mathbf{1 3 , 2 8}$ \\
\hline
\end{tabular}

(*): Analysis of significant variance at the 5\% threshold; (**): Analysis of highly significant variance at the $1 \%$ threshold; CV: Coefficient of variation; P-value: 5\% probability value; AUDPC: Area Under Disease Progress Curve

Table.2 Results of the analysis of variance of the dates 50\% flowering, "vegetable cowpea" and 95\% maturity of the studied varieties

\begin{tabular}{|c|c|c|c|c|c|}
\hline Variables & Minimum & Maximum & $\begin{array}{l}\text { Overall } \\
\text { average }\end{array}$ & P-Value (5\%) & $\mathrm{CV}(\%)$ \\
\hline 50\% flowering (JAS) & 34 & 47 & 42 & $0,0001 * *$ & 4,46 \\
\hline $\begin{array}{l}\text { Vegetable cowpea date } \\
\text { (VDD) }\end{array}$ & 48 & 59 & 52 & $0,0006^{*}$ & 4,62 \\
\hline 95\% maturity & 55 & 73 & 61 & $0,0001 * *$ & 3,65 \\
\hline
\end{tabular}

(*): Analysis of significant variance at the 5\% threshold; (**): highly significant analysis of variance at the $1 \%$ threshold;

CV: Coefficient of variation; P-value: $5 \%$ probability value 
Table.3 Results of analysis of variance of the number of pods per plant, number of seeds per pod, weight of one-hundred seeds, weight of seeds

\begin{tabular}{|l|c|c|c|c|c|}
\hline Variables & Minimum & Maximum & Overall average & P-Value (5\%) & CV (\%) \\
\hline Number of pods/Plant & 2 & 20 & 10 & $0.1866 \mathrm{~ns}$ & $\mathbf{3 6 , 6 7}$ \\
\hline Number of seeds/pod & 4 & 15 & 10 & $0,0056^{*}$ & $\mathbf{2 0 , 9 1}$ \\
\hline Seeds weight & 0,8 & 21,9 & 10,36 & $0,023^{*}$ & $\mathbf{2 8 , 9 6}$ \\
\hline $\begin{array}{l}\text { weight of one-hundred } \\
\text { seeds }\end{array}$ & 8,55 & 22,7 & 13,41 & $0,0001^{* *}$ & $\mathbf{1 3 , 2 5}$ \\
\hline
\end{tabular}

$(* *)$ : Analysis of variance highly significant at $1 \% ;(*)$ : Analysis of variance significant at 5\%; (ns): Analysis of variance not significant at 5\%; CV: Coefficient of variation; P-value: Probability value at 5\%

Table.4 Correlation matrix between the different variables studied

\begin{tabular}{|c|c|c|c|c|c|c|c|c|c|c|c|c|}
\hline Variables & DAS & SEV21 & SEV30 & Flo50 & SPAD & NGP & Mat95 & NGG & DNV & AUDPC & PGr & PCG \\
\hline DAS & 1 & & & & & & & & & & & \\
\hline SEV21 & $-0,265$ & 1 & & & & & & & & & & \\
\hline SEV30 & $-0,274$ & $0,736 * *$ & 1 & & & & & & & & & \\
\hline Flo50 & $-0,301$ & $-0,171$ & 0,096 & 1 & & & & & & & & \\
\hline SPAD & 0,098 & $-0,397$ & $-0,160$ & 0,270 & 1 & & & & & & & \\
\hline NGP & $0,151 *$ & 0,018 & $-0,014$ & $-0,290$ & $-0,124$ & 1 & & & & & & \\
\hline Mat95 & 0,046 & $-0,208$ & $-0,191$ & $0,629 * *$ & 0,362 & $-0,251$ & 1 & & & & & \\
\hline NGG & $-0,227$ & $-0,137$ & 0,162 & 0,269 & $-0,180$ & $-0,441 *$ & $-0,086$ & 1 & & & & \\
\hline DNV & $-0,009$ & $-0,299$ & $-0,216$ & $0,635 * *$ & 0,211 & $-0,146$ & $0,650 *$ & : 0,015 & 1 & & & \\
\hline AUDPC & $-0,290$ & $0,925 * *$ & $0,937 * *$ & $-0,034$ & $-0,293$ & 0,001 & $-0,213$ & 0,021 & $-0,274$ & 1 & & \\
\hline PGr & 0,109 & $-0,325$ & $-0,256$ & 0,129 & $-0,007$ & $0,519 *$ & 0,079 & 0,191 & $-0,011$ & $-0,310$ & 1 & \\
\hline PCG & 0,316 & $-0,515^{*}$ & $-0,496 *$ & 0,266 & 0,290 & $-0,310$ & $0,439 *$ & 0,212 & 0,130 & $-0,542 *$ & $0,428 *$ & 1 \\
\hline
\end{tabular}

(**): Highly significant correlation (1\%); (*): Significant correlation (5\%);SEV21: Severity in the 21st DAI; SEV30: Severity in the 30th DAI; FLO50: Date of $50 \%$ flowering; MAT95: 95\% maturity date; NGP: Number of pods per plant; NGG: Number of seeds per pod; DNV: Vegetable cowpea date; AUDPC: Area under disease progression curve; PGr: Grain weight; PCG: Weight of one hundred seeds; P-value: Probability value; DAS: Date of appearance of symptoms; SPAD: Plant chlorophyll content

Table.5 Contributions of variables to the axes (\%)

\begin{tabular}{|l|l|l|}
\hline & F1 & F2 \\
\hline DAS & 2,386 & 9,559 \\
\hline SEV21 & $\mathbf{1 9 , 0 0 8}$ & 2,118 \\
\hline SEV30 & $\mathbf{1 5 , 3 4 4}$ & 7,316 \\
\hline Flo50 & 3,867 & $\mathbf{2 5 , 3 4 0}$ \\
\hline SPAD & 5,852 & 1,152 \\
\hline NGP & 0,501 & $\mathbf{1 5 , 6 6 4}$ \\
\hline Mat95 & 8,385 & $\mathbf{1 2 , 6 6 8}$ \\
\hline NGG & 0,094 & 5,433 \\
\hline DNV & 6,761 & $\mathbf{1 1 , 5 0 8}$ \\
\hline ADCPM & $\mathbf{1 9 , 6 3 3}$ & 5,115 \\
\hline PGr & 3,838 & 4,104 \\
\hline PCG & $\mathbf{1 4 , 3 3 1}$ & 0,022 \\
\hline
\end{tabular}


Picture.1 Different symptoms caused by CABMV in the different cowpea varieties studied

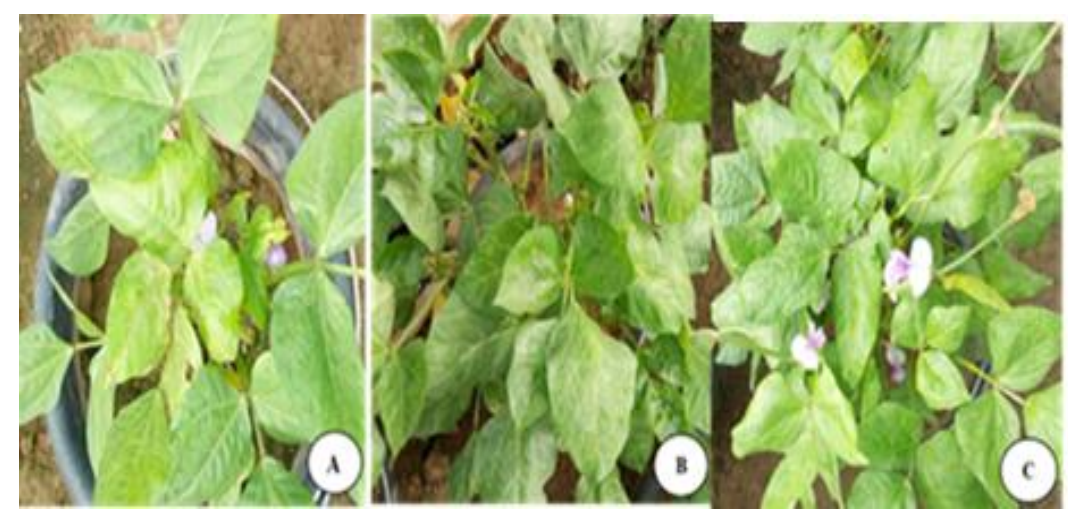

(A): yellow mosaic with leaf distortion in IT85F-2682; (B): green mosaic with leaf distortion in the form of leaf embossing in IT83S-911; (C): yellow and green mosaic visible only in backlighting with leaf distortion in IT85F2089-5

The highly significant differences for all parameters $50 \%$ flowering and date of vegetable cowpea would indicate the existence of varietal and production cycle diversity. Our results are close to those of PANDEY et al (2006) who found in their study varieties of vegetable cowpea that reached 50\% flowering in the shortest period such as Prakash (37 days) and varieties such as IT $86 \mathrm{~F}-2062-5$ and IT $86 \mathrm{D}-798$ that took a longer period (44 days) from sowing to flowering. Thus, varieties such as Niébé baguette, IT85F-2887 and IT85F-2089-5 which have flowering cycles of 36,39 and 40 JAS respectively would be early. This earliness can be assessed by the time of flowering or pod ripening (COBBINAH et al., 2011). The earliness of cowpea varieties is an important agronomic characteristic that could contribute to coping with climate change phenomena. According to BARRO (2016), in cowpea the number of days between the date of flower appearance and pod ripening remains constant. Thus, any increase in this time in the varieties studied would be related to damage caused by CABMV, as the viral attack delays flower and pod development (TIGNEGRE, 2000; NEYA, 2002; BARRO et al., 2016). The highly significant difference would indicate that the varieties in the study have different cycles for the vegetable cowpea date parameter. The vegetable cowpea cycle of the varieties studied, which is between 49 and 59 days after sowing, is close to that of VURAL et al (2000) who indicated that the harvest period for cowpea pods was 5 to 9 weeks after sowing. Thus, varieties that reached the vegetable pod stage between 49 and 51 days after sowing (JAS) could be classified as early. The varieties that reached the vegetable pod stage between 58 and 60 days after sowing (JAS) would be the latest. The cycle difference in vegetable cowpea date may be due to variety trait, planting time and growing environment (PANDEY et al., 2006).

The highly significant difference for the 95\% pod maturity date shows that the varieties tested did not reach their harvest date at the same time. However, all varieties reached their $95 \%$ maturity date in less than 70 days after sowing. These results confirm those of N'GBESSO et al., (2013), who consider that varieties with physiological pod ripening times of 67 to 70 days are early and varieties with 74 and 77 days have a slightly longer cycle. Thus, the varieties IT83S-872, IT85F2805, IT85F-867-5, IT85F-2887, IT85F2089-5, niébé baguette grimpant and niébé 
baguette with physiological pod ripening times of less than 60 days would be the earliest. The varieties IT85F-2682, IT83S911, IT85F-2082, Telma and komsaré would be the intermediate varieties.

The highly significant analysis of variance for weight of one-hundred-seed would also reflect variability within the varieties studied. The reduction in weight of one-hundred-seed could be attributed in part to a decrease in photosynthesis following a reduction in leaf area and thus in chlorophyll production. According to SINGH (1985), infected plants used less space and nutrients than healthy plants. The best varieties are those which showed a low severity value and a high weight of one-hundred-seeds (BARRO et al., 2018).

The varieties with low values of AUDPC were the least infected by CABMV and these could be qualified as resistant varieties. Variety IT85F-2089-5 with a severity equal to 1 and an AUDPC value equal to 9 had a moderately high weight of one-hundred-seed of $13.85 \mathrm{~g}$ while variety IT85F-872 with a severity equal to 5 and an AUDPC value equal to 40.5 had a weight of one-hundredseed of $9.4 \mathrm{~g}$. Disease progression in a plant, as far as viral disease is concerned, occurs only when new leaves develop, since symptoms cannot be expressed in old leaves (Van Loon, 1983). According to ORAWU (2007), the evaluation of AUDPC is used to select the best varieties for their ability to slow disease progression. Thus, disease symptoms were more visible at day 30 than at day 21 after sowing. Umaharan et al., (1997a) indicated that assessments made within 3 weeks after inoculation do not allow determination of resistance to symptom development. NDIAYE et al, (2010) also used this endpoint to assess the effects of compost on the development of Macrophomina phaseolina smut rot in cowpeas and showed that smut was more severe during the dry season than during the wet season.

The strong positive and highly significant correlation ( $r=0.9377)$ observed between AUDPC and severity at 30 DAI would show that as the severity increases, so does the area under disease progression curve. According to BARRO, (2016) the varieties with the lowest values of AUDPC and severity are resistant to CABMV. Induction of symptoms with reduced expression of severity in some varieties would therefore support their resistance status to the virus.

The highly significant and positive correlation observed between the $95 \%$ maturity date $(\mathrm{r}=0.62952)$ and $50 \%$ flowering, as well as between the green cowpea date $(r=0.63584)$ and $50 \%$ flowering would mean that the parameters maturity and green cowpea date can be predicted from 50\% flowering. The significant and negative correlation $(\mathrm{r}=$ 0.54218) between AUDPC and weight of onehundred-seeds would mean that the magnitude of the disease would lead to a reduction in weight of one-hundred-seeds. The significant and negative correlation between weight of one-hundred-seeds and severity at 30 DAI would be explained by the fact that weight of one-hundred-seeds and severity at 30 DAI vary in opposite directions.

The results of the principal component analysis showed the degrees of association of traits to explain the genetic diversity within the green cowpea varieties tested. Projection of the varieties in the PCA 1-2 plots shows that the varieties are randomly distributed in the plot. Such dispersal of varieties in the PCA design indicates significant genetic variability. The parameters correlated to axes 1 and 2 are therefore the determining parameters that explain most of the genetic variability between the varieties studied. The 
main discriminating parameters are: the date of symptom onset, severity at the $21 \mathrm{st}$, 30th JHA and the area under disease progression curve, the dates $50 \%$ flowering, "vegetable cowpea", 95\% maturity, and the number of grains per pod.

In conclusion the present study showed the existence of genetic variability within varieties not only for agronomic variables but also for resistance parameters to CABMV. Thus, the date of symptom onset, symptom severity and AUDPC are highly dependent on the variety of vegetable cowpea. Levels of infection varied significantly from one variety to another. On the basis of the analyses of the different results for the parameters of resistance to CABMV (DAS, severity, AUDPC), the vegetable cowpea varieties IT85F-2089-5 and Telma showed low severity values and the varieties IT83S-872, IT85F-867-5, IT85F-2895, IT83S-911, niébé baguette grimpant were characterized by extreme susceptibility. As for the vegetable cowpea stage, it was reached early by the varieties niébé baguette grimpant, IT85F-8675 and IT85F-2089-5. Highly positive, negative and highly significant correlations were noted between different parameters studied. The principal component analysis showed most of the genetic variability of the varieties studied.

\section{References}

Barro, A. 2016. Etude génétique de la résistance du niébé [Vigna unguiculata (L.)Walp] au Cowpea Aphid- Borne Mosaic Virus (CABMV) au Burkina Faso. Thèse de doctorat en Sciences Biologiques Appliquées. Université Ouaga I Pr Joseph KI-ZERBO, 98p.

Barro, A., Batieno, T. B. J., Sawadogo, N., Tignegre, J. B., Nanema K. R., Traore, R. E., and SAWADOGO, M. 2018. Resistance evaluation of five varieties of cowpea and their F1 descendants from a diallelcrossing to cowpeaaphid-borne mosaicvirus in Burkina Faso. International Journal of Biologicas and Chemicas Sciences. 12(2): 668-675p.

Cobbinah, F.A., Addo-quaye, A.A., and ASANTE I.K. 2011.Characterization, Evaluation And Selection Of Cowpea (Vigna unguiculata (L.) Walp) accessions withdesirable traits fromeightregions of ghana, ARPN. Journal of Agricultural and Biological Science, 6(7): 21-32.

Faostat. 2016. Production végétale, quantité produite et superficies emblavées: htt://faostat.fao.org.

Fischer, H. U., and Lockhart B. E. 1976. A strain of cowpeaaphid-borne mosaic virus isolated from cowpeas in Morocco. Phytopathologische Zeitschrift 85:43-48p.

Guinko, S. 1984. Végétation de la HauteVolta. Thèse de Doctorat ès Sciences Naturelles. Université de Bordeaux III (France). Tome 1, $318 \mathrm{p}$.

Jackson, J. C. 2009. Protein nutritional quality of cowpea and navy bean residue fractions. African Journal of Food Agriculture and Development, 9:pp 764778.

Kidigodi, M. S. 1985. Contribution à l'étude de la résistance aux insectes de quelques cultivars sélectionnés du niébé [Vigna unguiculata (L.) Walp] à Gampèla. Mémoire I.D.R. Université de Ouagadougou, 52p.

Meteo Inera, 2018. Relevé des quantités d'eau tombées et des températures au cours de la campagne 2017/2018.

Modu, Y., Putai, A. J., and Petu-ibikunle, A. M. 2010. An Economic Analysis of Cowpea Production among Women Farmers in Askira/Uba Local Government Area Borno State Nigeria. African Journal Genetic of Agriculture, 6: 7-17. http://www.asopah.org. 
N'gbesso, F-P. M., Fondio, L., Dibi, B. E. K., Djidji, H. A., and KOUAME C. N. 2013. Etude des composantes du rendement de variétés améliorées de niébé. Journal of Applied Biosciences 63: pp 4754-4762, ISSN 1997-5902.

Ndiaye, M., Termorshuizen, A. J., and VAN Bruggen, A. H. C. 2010. Effcts of compost amendment and the biocontrol agent Clonostachysrosea on the development of charcoal rot (Macrophomina phaseolina) on cowpea. Journal of Plant Pathology 92, pp. 173180.

Neya, B. J. 2002.Variabilité sérologique et aspects épidémiologiques du virus de la mosaïque du niébé (Vigna unguiculata (L.) Walp.) transmis par des pucerons au Burkina Faso. Mémoire de D.E.A., Université de Ouagadougou, $46 \mathrm{p}$.

Neya, B. J. 2011.Sérologie, pathologie, épidémiologie et contrôle de la mosaïque cowpeaAphid Borne Mosaic Virus (CABMV) du niébé (Vigna unguiculata (L.) Walp.) Transmise par des pucerons (Aphidcrassivora, A. gossypii) au Burkina Faso. Thèse de doctorat, Université de Ouagadougou, $153 \mathrm{p}$.

Nualsri, C., and Konlasuk S. 2000. Establishment of experimental condition on RAPD (randomamplified polymorphic DNA) analysis of Lansium domesticum Correa. I. DNA extraction fromleafsample. Songklanakarin Journal of Sciences. 22, pp. 403-410.

Orawu, M. 2007. Occurrence of cowpea aphidbornemosaic virus and prospects of improving resistance in local cowpea landraces in uganda. Thesis, University of Kwazulu-Natal, 137p.

Orawu, M., Melis, R., Laing, M., and DERERA, J. 2012.Geneticinheritance of resistance to cowpea aphid-borne mosaic virus in cowpea. Euphytica, 189(2), pp 191-201.
Pandey, Y. R., Pun, A. B., and Mishra, R. C. 2006. Evaluation of Vegetable Type Cowpea Varieties for Commercial Production in the River Basin and Low Hill Areas. Nepal Agricultures Ressources Journal Vol. 7. Pp 16-20.

Reeves, W. H. 1983. Le niébé. International Institute of Tropical Agriculture. Ibadan Nigeria, $170 \mathrm{p}$.

Shaner, G., and Finney, R.E. 1977. The effect of nitrogen fertilization on the expression of slow-milde wing resistance in Knox wheat. Phytopathology, 67: pp 1051 -1056.

Singh, S. R., and Jackai, L. E. N. 1985.Insectpests of cowpea in africa: Their life cycle, economic importance and potential of control. Pages 218-231 in: Cowpea research, production and utilization. Edit. SINGH S. R. and RACHIE K. O., JOHN WILEY and SONS Ltd.

Singh, S. R. 1985.Insectsdamagingcowpea in Asia. Pages 245-248 in: Cowpea research, production and utilization. Edit. SINGH S. R. and Rachie K. O., John Wiley and SONS Ltd.

Thiombiano, A., and Kampmann, 2010. Atlas de la biodiversité de l'Afrique de l'ouest, Tome II, Burkina Faso, Ouagadougou et Frankfurt/Main.

Tignegre, J. B. 2000. Etude de la transmission du Cowpea Aphide-Borne Mosaic Virus (CABMV) par les graines chez le niébé [Vigna unguiculata $(L)$ Walp.] Mémoire de DEA, UFR/SVT université de Ouagadougou, 65pp.

Umaharan, P., Ariyanayagam, R. P., and Haque, S. Q. 1997a.Resistance to cowpeaseveremosaic virus, determined by three dosage-independentgenes in Vigna unguiculata (L.) Walp. Euphytica 95:pp 49-95.

Van Loon, L. C. 1983. Mechanism of resistance in virus infected plants, In: The Dynamics of Host Defence, edite by 
J.A. Bailey and B.J. Deverall. AcademicPress, Sydeny and New York. Vural, H., Esiyok, D., and Duman, I. 2000. Cultivated Vegetables (Vegetable Cultivation). Ege University, Bornova, Izmir, Turkey. Conservation and nutrient management on the soil-plant water balance in semi-arid Burkina Faso. Agricultural Water Management,
65: 103-12.

Zougmore, R., Mando, A., and Stroosnijder, L. 2004. Effect of soil and water conservation and nutrient management on the soil-plant water balance in semiarid Burkina Faso. Agricultural Water Management, 65: 103-1.

\section{How to cite this article:}

Nanama Joseph, Barro Antoine, Batieno Benoit Joseph, Dieni Zakaria, Kiebre Zakaria, Coulibaly Zinmanké and Sawadogo Mahamadou. 2020. Genetic Study of the Resistance of Twelve (12) Varieties of Vegetable Cowpea [Vigna unguiculata (L.) Walp. ] to Cowpea AphidBorne Mosaic Virus, Burkina FASO. Int.J.Curr.Microbiol.App.Sci. 9(11): 2032-2043. doi: https://doi.org/10.20546/ijcmas.2020.911.242 